\title{
Hydrogeochemical processes as environmental indicators in drip water: Study of the Cueva del Agua (Southern Spain)
}

\author{
Angel Fernandez-Cortes ${ }^{1,2}$, Jose Maria Calaforra ${ }^{2}$, Francisco Sánchez-Martos ${ }^{2}$
}

\begin{abstract}
:
Fernandez-Cortes A., Calaforra J.M., Sánchez-Martos F. 2008. Hydrogeochemical processes as environmental indicators in drip water: Study of the Cueva del Agua (Southern Spain), 37 (1), 41-52. Bologna (Italy). ISSN 0392-6672.

Karst caves exhibit a wide range of hydrological and hydrochemical responses to infiltration events, due to their physical heterogeneity in space and dynamic variability over time, and due to non-Gaussian inputs (rain) and outputs (discharge). This paper reviews different approaches of studying seepage water in caves, in order to understand the infiltration regimen in the non-saturated zone of karst areas. As an illustration, we describe a four-year study of the active carbonate-water system in the Cueva del Agua (Granada, southern Spain) that automatically logs the discharge from a stalactite. The results indicate that: (1) the drip water regime is not seasonal, but is linked instead to slow infiltration. Sudden changes in drip water regime occur due to infiltration along preferential flow paths and the draining of water of supersaturated water from reserves in the microfissure and pore system; (2) the drip rate is not linear over time. When dripping is constant, barometric oscillation of the air is the principal factor causing a chaotic a drip flow regime. Over a short period of two to three days, a mean variation in air pressure inside the cave of $10( \pm 3.7)$ mbar causes a mean oscillation in the drip rate of $0.5( \pm 0.2) \mathrm{mm} / \mathrm{h}$. The increase in air pressure translates into an increase in the relative thickness of the gaseous phase of the drip water at the cost of the aqueous phase, so leading to a reduction in the drip rate from the stalactite.

Keywords: Drip discharge, piston effect, speleothems, karst, cave.
\end{abstract}

Received 30 July 2007; Revised 20 November 2007; Accepted 23 November 2007

\section{INTRODUCTION}

The hydrodynamic processes and mechanisms involved in rain infiltration and recharge in karst terrains can be identified and quantified by measuring seepage from cave stalactites. Unlike the diffuse recharge that prevails in porous media, the processes and mechanisms involved in recharge of a highly heterogeneous, karstic environment are not easily characterized. A great variety of factors controls the quantity and composition of the water inflow into caves. Climate determines timing and quantity of water input, and the proportion that falls as snow, which could be recycled by evaporation. Climate (and thus altitude and topography) influence vegetation cover, whose development strongly affects the chemistry of the carbonate system and soil properties (Fairchild et al., 2007). The aquifer itself has a complex response

1Environment and Earth Science Department - Applied Petrology Lab, University of Alicante, Ap. 99, 03080 Alicante, Spain. acortes@ua.es

2 Water Resources and Environmental Geology Research Group, University of Almería, Cañada de San Urbano, s/n. 04120, Almería, Spain.jcalafor@ual.es; fmartos@ual.es to water infiltration events. Karstic aquifers have a complex of pore spaces in their matrix, including one-dimensional conduits and fractures, all of which facilitate mixing and these structures gives rise to a wide range of transmission times in the unsaturated zone.

Variations in fluid composition are predominantly a function of the groundwater residence time and interaction of the water with overlying soils and the host aquifer carbonate rocks. The $\mathrm{pCO}_{2}$ of the water increases as it passes through the soil and epikarst plays a key role on speleogenesis and the geochemistry of drip waters in caves. Seasonal patterns in $\mathrm{pCO}_{2}$ are commonly found in karst soils and these are transmitted to the cave environment, leading to seasonal changes in water hardness and growth rate of speleothems.

Studies of frequently-measured or automaticallylogged discharges (Smart \& Friederich, 1986; Baker et al., 1997, Genty \& Deflandre, 1998; Tooth \& Fairchild, 2003; Baker \& Brunsdon, 2003; Sondag et al., 2003; Fairchild et al., 2006, Fernandez-Cortes et al., 2007; McDonald \& Drysdale, 2007) illustrate a range of hydrological responses to infiltration events. An alternative focus of some studies has been 
the combined analysis of temporal variation of the discharge and geochemical changes in the drip water, using:

(1) Major dissolved ions, like $\mathrm{Ca}^{2+}, \mathrm{Mg}^{2+}, \mathrm{Na}^{+}, \mathrm{K}^{+}$, etc. (Carrasco et al., 1995; Covelli et al., 1998; Cardenal et al., 1999; Fairchild et al., 2000; Huang et al., 2001; Huang \& Fairchild, 2001; Musgrove \& Banner, 2004) which rations permits to characterize the fluid/gas proportion and non-conservative mixing processes in unsaturated zone upper the cave (Baker et al., 2000; Tooth \& Fairchild, 2003; Fairchild et al., 2006).

(2) Organic compounds contained in the drip water from stalactites, evaluated on the basis of luminescence rates, allow the distinction between different sources of infiltration as a function of the residence time of the water in soils and/or host rock (Baker et al., 1997, 2000; Baker \& Barnes, 1998; van Beynen et al., 2000, 2002; Tatár et al., 2004; Cruz et al., 2005).

(3) Stable isotopes of strontium, hydrogen, oxygen and carbon, as well as tritium, have been used to study infiltration, fractionation processes and residence times of water in the unsaturated zone and, of course, in paleoclimatic studies comparing the isotope composition of cave deposits (Chapman et al., 1992; Bar-Matthews et al., 1996; Li et al., 2000; Kaufman et al., 2003; Perrin et al., 2003; Musgrove \& Banner, 2004).

The present study developed on the Cueva del Agua (Granada, Spain) contributes with new data to the knowledge about water flow through the upper part of unsaturated karstic zone, specially refereed to semiarid conditions. Predominantly, researchers who are interested in karst hydrology have studied springs and underground rivers, which compose the fast flow drainage system. However, the slow component of karst infiltration is not very well known and it appears that monitoring stalactite drip rate is a new way to improve our understanding of the karst structure, and particularly its porosity and small fissure network. The interest of this research is to improve our knowledge of seepage dynamics in karst terrain, following the research line initiated by Genty \& Deflandre (1998) and Baker \& Brunsdon (2003), by using time series records of drip rate, electrical conductivity and temperature of drip water, air pressure and rainfall. A drip site was chosen after several trial measurements within cave until getting a drip point with an average value of a wide range of discharges. Statistical analysis and simple numerical models were used to seek relationships between environmental atmospheric characteristics (air pressure, rainfall and water excess) and seepage recharge.

\section{DESCRIPTION OF THE SITE}

The Cueva del Agua is situated $1746 \mathrm{~m}$ above mean sea level on the change of slope of the Sierra Harana (Southern Spain). The cave has formed in a dolomitic limestone formation in the Lower Lias, which is $900 \mathrm{~m}$ thick. This formation comprises two layers: a highlytectonized dolomitic base and an overlying white limestone layer. The Cueva del Agua developed at the contact between the inferior brecciated dolostones and the overlying unit of white limestones, along the plane of a reverse fault (Fig. 1A). The orientation of the cave follows steep gradients of up to $37 \%$, coinciding with the surface topography and practically coinciding with the dip of the fault plane (E-NE) in which the cave has developed. Thus, the geomorphology of the outside environment does not encourage the accumulation of water in depressions in the terrain but does encourage surface run-off. Nevertheless, the loss of excess rainfall through run-off can be dismissed since there is practically no soil on the surface and a lapies extends over the whole area (Fig. 2). In addition, direct infiltration of excess rainfall is significantly favoured in the epikarst, due to the intense fracturing and the subvertical stratification of the white limestones that enclose the cave.

The climax vegetation in the vicinity of the Cueva del Agua is Mediterranean Holly Oak woodland (Quercus rotundifolia), but this is in a regressive stage in the vegetation series. This natural succession is accentuated at altitude and is represented by a "matorral" degradation series, comprising cushionforming spiny plants such as the "piorno" ("hedgehog" broom, Erinacea anthyllis), hawthorn (Crataegus monogyna), wild rose (Rosa sp.) and "esparto" grass (Festuca scariosa) (González-Ríos \& MarínMaldonado, 1994). These plant species withstand less benign environmental conditions, and take advantage of the scarce soil cover and the humidity in the discontinuities in the limestones.

\section{METHODS}

An environmental monitoring system has been installed in the Cueva del Agua since 1994. Interpretation of continuous logging data has allowed the creation of environmentally sustainable management tools for the managers of this show cave (Calaforra et al., 2003; Fernandez-Cortes, 2005; Fernandez-Cortes et al., 2006 and 2007). Part of this underground laboratory is dedicated to monitoring of water infiltration. It consists of an outdoors meteorological station, an interior station to monitor dripping from a stalactite in the Endriagos chamber and a second station that records the barometric air pressure inside the Gran Caverna (Fig. 1B). The Endriagos chamber is at some $35 \mathrm{~m}$ depth and approximately $95 \mathrm{~m}$ from the cave entrance (Fig. 3). The outdoors weather station includes a tipping-bucket rain gauge with an accuracy and resolution of $\pm 0.2 \mathrm{~mm}$, an air temperature sensor (resistivity type with a range of measurement of -25 to $+100{ }^{\circ} \mathrm{C}$, accuracy of $\pm 0.2^{\circ} \mathrm{C}$ between 0 and $70{ }^{\circ} \mathrm{C}$ and a digital resolution of $0.1^{\circ} \mathrm{C}$ ), and an atmospheric pressure sensor with a resolution and accuracy of $\pm 0.1 \mathrm{mbar}$ and a range of measurement of 600 to 1150 mbar.Drip intensity from the stalactite is monitored inside the Endriagos chamber by means of a tippingbucket rain gauge with an accuracy of $\pm 0.2 \mathrm{~mm}$ (Fig. 4). The drip water collected in the gauge is stored in a $100 \mathrm{ml}$ receiver, which contains an electrical 

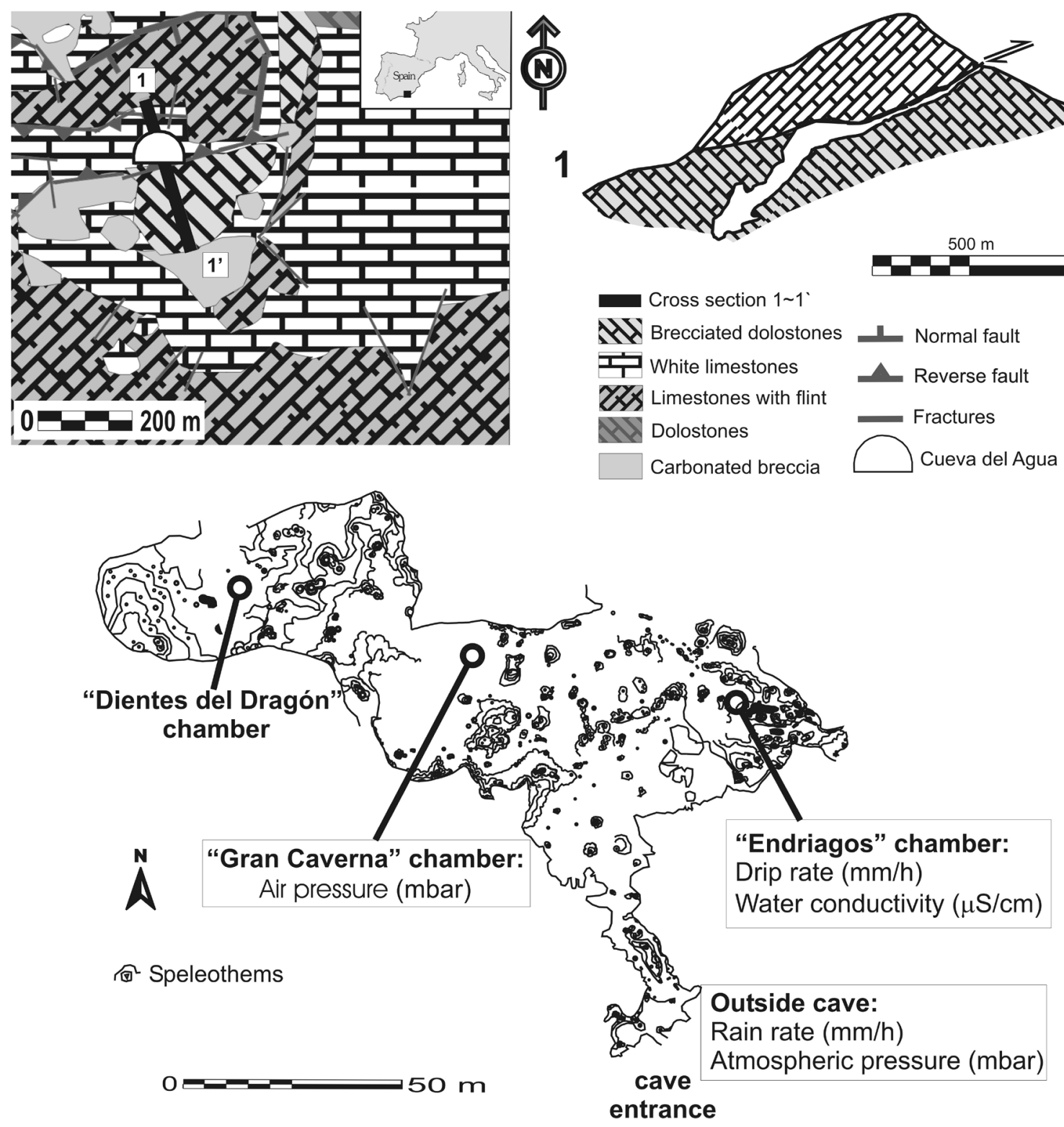

Fig. 1. A: Geological map scheme of the Cueva del Agua area with the main lithologies, faults and fractures (simplified from Perez-Lopez, 1986) and cave profile from the cave entrance as far as the Dientes del Dragón chamber, in relation to the ground surface. B: Detailed topography of the largest chambers of the cave and situation of the infiltration monitoring station.

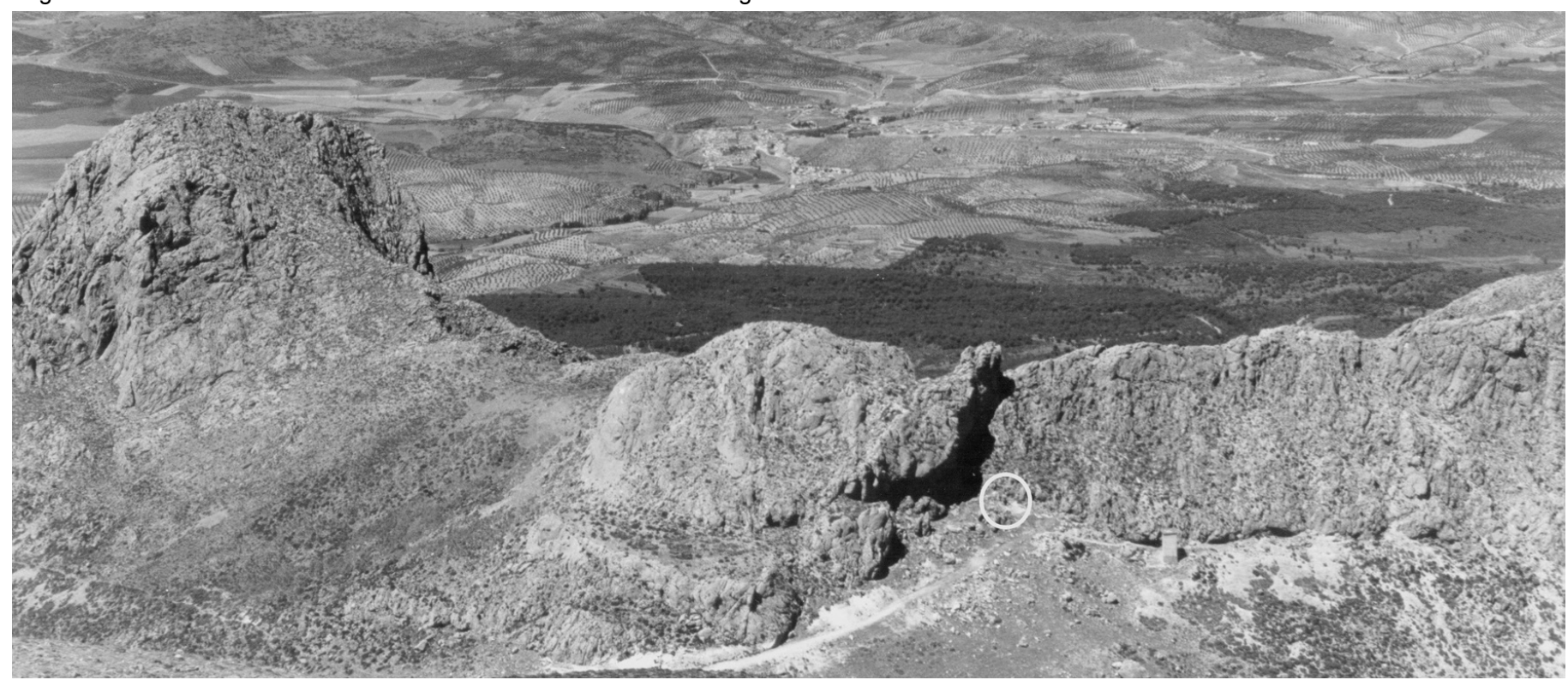

Fig. 2. Panoramic view of the Cueva del Agua entrance (marked with a white circle), showing the contact between the inferior brecciated dolostones (base) and the overlying unit of white limestones (vertical stratum) (Photo: M. Gonzélez-Ríos). 


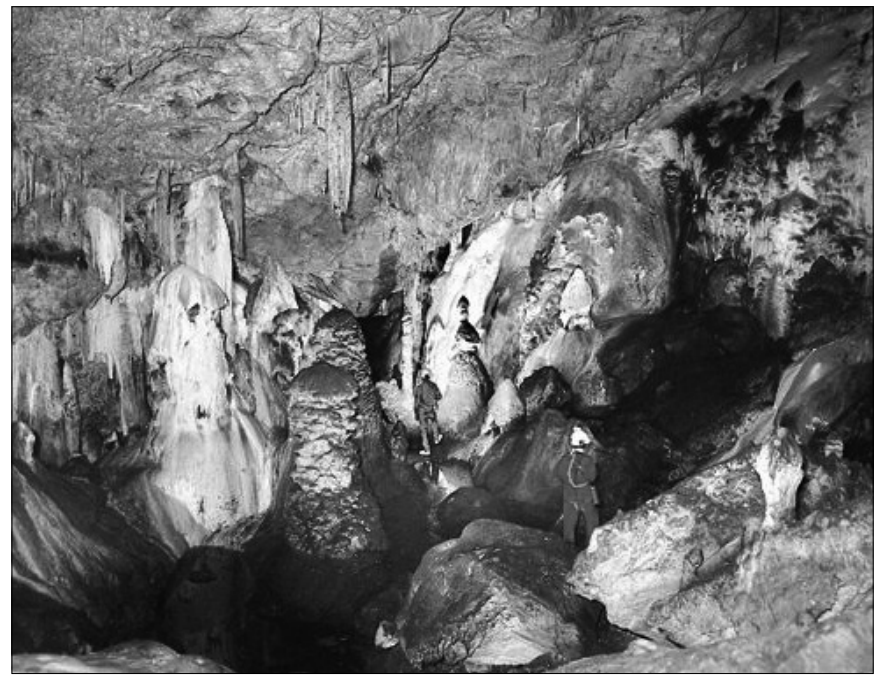

Fig. 3. Partial view of the Endriagos chamber (Author: M. GonzálezRíos).

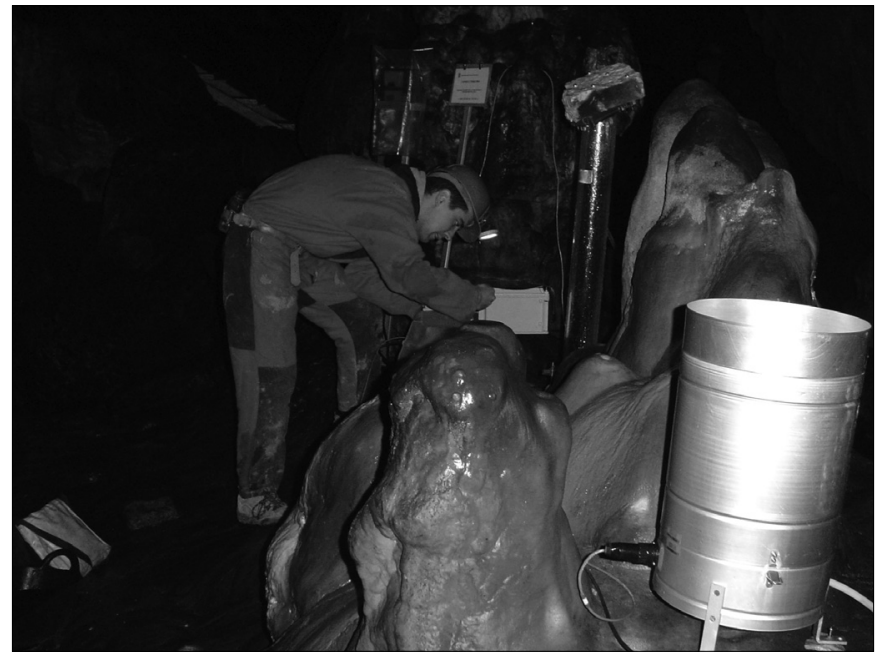

Fig. 4. Control station in Endriagos chamber for monitoring drip rate and electrical conductivity of water.

conductivity sensor, with a range of 100 to 1000 $\mu \mathrm{S} / \mathrm{cm}-1$ (accuracy $\pm 0.2 \mu \mathrm{S} / \mathrm{cm}-1$ and resolution $0.1 \mu \mathrm{S} / \mathrm{cm}-1)$. Lastly, the Gran Caverna houses a monitoring station for barometric air pressure, which has a resolution and precision of $\pm 0.1 \mathrm{mbar}$ and a measurement range of 600 to 1150 mbar. All stations take hourly readings of the variables, and these data are stored on Thermos-data dataloggers (Digital Analog System, 1993). This sampling interval was adopted in function of memory capacity of loggers, battery life of power suppliers and taking account the high stability of microclimate conditions and drip rate during previous trial months.

\section{RESULTS}

Over the hydrological years $1997 / 2002$, the average water excess was $67 \%$ of the precipitation. The percentage was lower during drier years $139 \%$ in 1998/1999). Mean daily water excess in the period 1997-2002 was $2.5 \mathrm{~mm}$, and the maximum was 123 $\mathrm{mm} /$ day. The water deficit generally coincided with the summer months and the onset of autumn; deficits reached around $20 \mathrm{~mm}$, except during the hydrological year 1997/1998, when it reached $50 \mathrm{~mm}$. summarise the monthly totals of excess rainfall, calculated for 1997-2002 using Thornthwaite's method (1954); this method allows a daily water balance to be calculated using the mean monthly temperatures over the period.

The mean annual precipitation outside the Cueva del Agua was $952 \mathrm{~mm}$ over the period 1997-2002. The mean monthly distribution of the rainfall over this period contains two peaks, characteristic of a continental Mediterranean climate: the maximum occurred in autumn (177 $\mathrm{mm}$ in November) with a relative peak occur in spring (105 $\mathrm{mm}$ in March). It encompassed dry spells with no rainfall and days of peak rainfall for which mean daily rainfall was 5.1 $\mathrm{mm}$. Over the period 1997-2002 the mean hourly precipitation was $0.1 \mathrm{~mm} / \mathrm{h}$, and a maximum, 22 $\mathrm{mm} / \mathrm{h}$.

The mean height of Endriagos chamber is $14 \mathrm{~m}$ and the white limestones that form its roof are 35-40 m thick, extending to the ground surface. The surface area of the Endriagos chamber is about $481 \mathrm{~m}^{2}$, which represents $4 \%$ of the total cave area $\left(12,920 \mathrm{~m}^{2}\right)$. Bearing in mind the area of the cave and the total excess rainfall over the study period $(3,400 \mathrm{~mm}$ over 1997-2002), the volume of drip water collected from the stalactite in the Endriagos chamber represented $0.1 \%$ of this volume. In spite of being a tiny percentage of the total volume, the characteristics of the drip regime of this stalactite perfectly correlate with the year-to-year variation of the excess rainfall; thus, the hydrological operation of the dripping responds to the general infiltration process occurring in the cave and the dripping stalactite chosen is considered as representative. Dripping continues all year long, despite a soil moisture deficit occurring each summer, suggesting that there must be a significant storage flow component to this drip such that drip rate is maintained all year. Drip rates of this point respond to periods of hydrologically effective precipitation, showing that there is also a probable fissure flow component.

The mean drip rate in the Endriagos chamber is 1.3 $( \pm 1) \mathrm{mm} / \mathrm{h}$. The peak hourly drip water discharge is $5 \mathrm{~mm} / \mathrm{h}$. summarises the year-to-year variation in drip rate and total volume drained by the Endriagos stalactite over the five year period (1997-2002). The highest discharge of drip water occurred during the first hydrological year $(16,445 \mathrm{~mm}$ in $1997 / 98)$, whilst in the following year $(1998 / 1999)$, the drip water discharge fell by $70 \%$ (4907 $\mathrm{mm}$ ). In the subsequent years the volume of drip water was more homogeneous, at around 12,600 $\mathrm{mm} /$ year.

The physico-chemical parameters monitored are water temperature and electrical conductivity. Drip water temperature for the years 1997-2002 varied from 8.1 and $9.6^{\circ} \mathrm{C}$, with an overall mean of $9.5^{\circ} \mathrm{C}$ $\left(\sigma=0.2^{\circ} \mathrm{C}\right)$. Overall, mean electrical conductivity was $325( \pm 23) \mu \mathrm{S} / \mathrm{cm}$, oscillating between 268 and 369 $\mu \mathrm{S} / \mathrm{cm}$.

Over the study period, the mean daily air pressure of the outside air was 753 mbar, with a typical deviation of 13 mbar. Inside the cave the mean daily 


\begin{tabular}{|c|c|c|c|c|c|}
\hline Water excess $(\mathrm{mm})$ & $1997 / 1998$ & $1998 / 1999$ & $1999 / 2000$ & $2000 / 2001$ & $2001 / 2002$ \\
\hline September & 35 & 0 & 3 & 0 & 0 \\
\hline October & 13 & 0 & 299 & 49 & 71 \\
\hline November & 405 & 0 & 38 & 172 & 68 \\
\hline December & 282 & 0 & 98 & 327 & 124 \\
\hline January & 49 & 45 & 0 & 222 & 35 \\
\hline February & 87 & 41 & 0 & 45 & 0 \\
\hline March & 12 & 75 & 0 & 208 & 118 \\
\hline April & 62 & 0 & 232 & 0 & 105 \\
\hline May & 60 & 0 & 0 & 20 & 0 \\
\hline June & 0 & 0 & 0 & 0 & 0 \\
\hline July & 0 & 0 & 0 & 0 & 0 \\
\hline August & 0 & 0 & 0 & 0 & 0 \\
\hline Total (mm) & 1005 & 161 & 670 & 1043 & 521 \\
\hline
\end{tabular}

Table 1. Water excess variations outside Cueva del Agua during hydrological period 1997-2002.

\begin{tabular}{|c|c|c|c|c|c|c|c|c|c|c|}
\hline \multirow{2}{*}{$\begin{array}{l}\text { Stalactite } \\
\text { Drip }(\mathrm{mm})\end{array}$} & \multicolumn{2}{|c|}{$1997 / 1998$} & \multicolumn{2}{|c|}{$1998 / 1999$} & \multicolumn{2}{|c|}{$1999 / 2000$} & \multicolumn{2}{|c|}{$2000 / 2001$} & \multicolumn{2}{|c|}{$2001 / 2002$} \\
\hline & Average & Total & Average & Total & Average & Total & Average & Total & Average & Total \\
\hline September & 0.3 & 180.4 & 0.3 & 213.0 & 0.7 & 498.0 & 0.2 & 165.6 & 0.3 & 197.0 \\
\hline October & 2.0 & 1464.2 & 0.2 & 129.6 & 1.1 & 795.2 & 0.2 & 139.2 & 1.0 & 739.0 \\
\hline November & 3.5 & 2519.4 & 0.2 & 109.0 & 2.6 & 1866.0 & 2.3 & 1669.0 & 2.3 & 1646.4 \\
\hline December & 2.5 & 1848.6 & 0.1 & 98.2 & 2.6 & 1942.8 & 2.9 & 2188.8 & 2.2 & 1598.0 \\
\hline January & 2.5 & 1846.8 & 0.1 & 99.0 & 2.1 & 1577.0 & 2.5 & 1844.8 & 2.4 & 1784.4 \\
\hline February & 2.4 & 1634.6 & 0.2 & 100.6 & 0.7 & 494.2 & 2.5 & 1658.2 & 2.0 & 1348.2 \\
\hline March & 1.3 & 973.2 & 2.2 & 1627.4 & 0.7 & 520.6 & 2.2 & 1618.2 & 2.1 & 1529.6 \\
\hline April & 1.4 & 1016.0 & 1.6 & 1113.8 & 2.0 & 1401.4 & 1.1 & 819.6 & 2.1 & 1488.4 \\
\hline May & 2.8 & 2101.4 & 0.6 & 456.2 & 2.3 & 1682.6 & 1.2 & 916.8 & 1.1 & 798.0 \\
\hline June & 2.4 & 1758.0 & 0.3 & 221.8 & 1.4 & 987.4 & 1.3 & 935.2 & 0.5 & 336.8 \\
\hline July & 1.0 & 716.2 & 0.3 & 242.0 & 0.5 & 385.2 & 0.7 & 523.0 & 1.0 & 776.8 \\
\hline August & 0.5 & 386.2 & 0.7 & 496.6 & 0.3 & 220.6 & 0.4 & 279.6 & 0.6 & 470.2 \\
\hline Year & 1.9 & 16445.0 & 0.6 & 4907.2 & 1.4 & 12371.0 & 1.5 & 12758.0 & 1.5 & 12712.8 \\
\hline
\end{tabular}

Table 2. Year-to-year variation of drip rate and total volume drained by the stalactite in the Endriagos chamber over hydrological years $1997-2002$.

pressure was 805 mbar, with a typical deviation of 7 mbar. Hourly barometric changes of the outside air registered a mean of 2.4 mbar and a maximum of 18.2 mbar, whereas the mean hourly change in air pressure inside was 2.1 mbar, with a maximum of 16.9 mbar.

\section{INTERPRETATION OF RESULTS}

\section{Inter-annual and seasonal variations of infiltration}

Mean drip rate was positively correlated with the volume of water dripping from the stalactite. Both variables are highly dependent on the rainfall regime. The within-year variation of drip rate and drip volume give relative peaks in autumn and spring, with a summer minimum, all of which obviously coincides with the seasonal pattern of rainfall outside the cave.

Between- and within-year variability of drip rate in the Endriagos chamber are indicative of the character of the infiltration in the vadose zone that envelops the cave. Thus, an increase in the temporal variation in drip rate is due to processes of rapid recharge in the cave along preferential conduits, associated with intense rainfall events outside the cave. In turn, the variability of the discharge in a cave also increases with total precipitation (Baker et al., 1997; Genty \& Deflandre, 1998). By comparing the degree and variability of the discharge over one or several hydrological years, a hydrological classification of the infiltration processes in the cave can be made (Smart $\&$ Friedrich, 1987). According to these authors, the high-intensity discharge events in a cave, which give an elevated coefficient of variation, correspond to processes of rapid percolation and vadose flow along preferential conduits. Meanwhile, the low intensity discharges commonly detected in the cave are associated with water reserves held in the system of microfissure and pores in the vadose zone. For the latter type of water discharge, a higher or lower coefficient of variation over a specific interval of time (e.g., a hydrological cycle) will show the seasonal or continuous character of drip discharges over time. The mean drip rate of a stalactite falls within the range $5 \cdot 10^{-4}$ to $0.51 / \mathrm{h}$, with a coefficient of variation of $50 \%$. In the case of the Endriagos chamber the 
dripping is not seasonal, but is linked to the process of slow infiltration (Fig. 5). The summer months are grouped on the graph around a mean monthly mean of $10^{-4} 1 / \mathrm{s}$ and with a coefficient of variation of 20 $35 \%$. In contrast, there is a generally higher drip rate over the remaining months that cover the whole interval of the coefficient of variation for this type of non-seasonal dripping (0-50\%).

The pattern of non-seasonal dripping by slow infiltration detected to the Endriagos chamber is occasionally replaced by a seasonal drip pattern, characterised by a similar mean monthly drip rate, but with a monthly variation coefficient of more than $50 \%$ of the drip rate intensity. Change from nonseasonal to seasonal dripping occurs in the autumn, when intense precipitation begins again after the dry summer period. In this way, the monthly variability of the drip rate increases. The monthly variability of the drip rate also increases with the spring peak rainfall, and with the onset of the winter and summer low rainfall periods. The changes in drip regime 2,3 and 6 (Fig. 5) are caused by the water-filled of voids in the vadose zone and by peak rainfall events (of 22.0, 20.4 and $5.4 \mathrm{~mm} / \mathrm{h}$, respectively), which trigger the sudden dislodging of the water reserve held in the system of microfissures and pores in the unsaturated zone. In each case, these peak hourly precipitations are higher than the mean daily maxima $(5 \mathrm{~mm} / \mathrm{h})$ throughout the hydrological period 1997-2002. The increases in monthly variation monthly of the drip rate identified as 1,4 and 5 (Fig. 5) are related to drastic declines in the drip rate in Endriagos chamber as a result of the lack of the excess rainfall that supplies the drip water. Thus, during processes 1, 4 and 5 , the hourly maximum precipitation recorded was less than the mean $(5 \mathrm{~mm} / \mathrm{h}),-$ specifically 0.0 , 4.6 and $3.2 \mathrm{~mm} / \mathrm{h}$ respectively. A comparison of the mean monthly drip intensity during the period of non-seasonal drip regime (slow infiltration) and the months when seasonal dripping occurs, confirms that, except during the summer months, the slow infiltration delivers a larger volume of water to the cave than the rapid infiltration events (i.e., the drip regime with a seasonal character). Widening the scale of observation from monthly to annual, it is clear that the between-year variability of the drip discharge is significantly greater than the within-year variability.

\section{Recharge events caused by the piston effect}

The variation in electrical conductivity of the drip water is closely linked to the residence time of the infiltration water in the unsaturated zone and, therefore, with its degree of saturation. A comparison

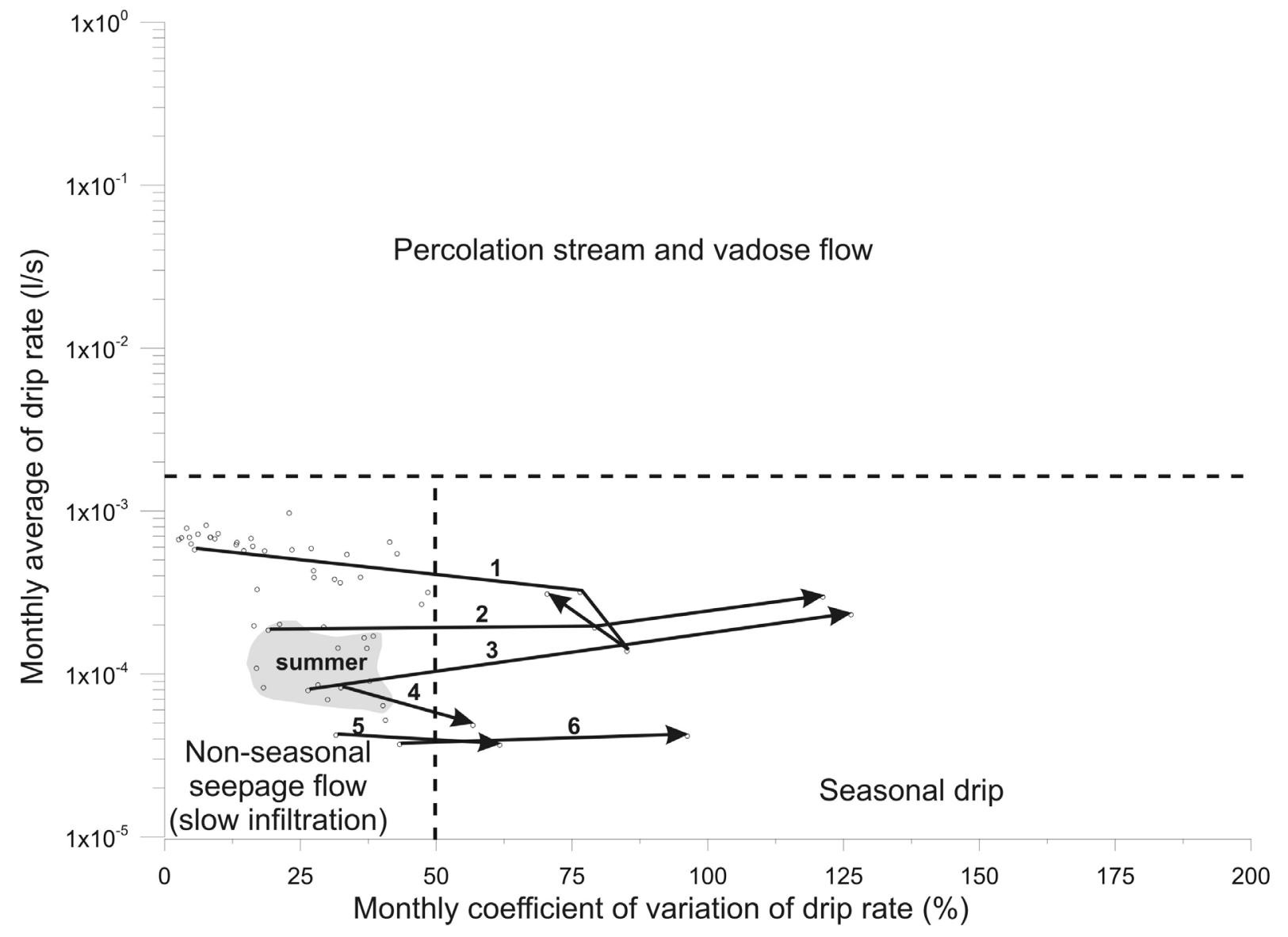

Fig. 5. Hydrological classification of the infiltration process into the Endriagos chamber (Cueva del Water). The arrows represent the change from a monthly regime of non-seasonal to seasonal dripping. (modified from Smart and Friedrich, 1987) 
of the sharp increases in drip rate and the behaviour of electrical conductivity detects the phenomenon of the "piston effect", which dislodges the reservoir of supersaturated water. These events, which cause a sudden jump in the drip rate, usually occur in autumn (September-November) and at the beginning of spring (March-April). Triggering recharge into the cave via the piston effect first requires a water-filled of the pores and microfissures of the unsaturated zone following a long period of evapotranspiration. Subsequently, excess rainfall infiltrates into the epikarst, filling the conduits and raising the hydraulic pressure in the vadose zone overlying the supersaturated water mass. Finally, this water reserve is flushed out of the microfissure and pore system of the karst matrix and flows along preferential flow paths, entering the cave as drip water through stalactites, flowstones, etc. From a hydrogeochemical point of view, a recharge event due to the piston effect will cause a sudden increase followed by a gradual decline in the electrical conductivity of the infiltration water.

Events when the drip rate rises imply a change in the recharge regime into the cave through the overlying unsaturated zone, moving from a state of least recharge to one of peak recharge. The opposite change, from a state of peak to one of minimal recharge occurs by means of a gradual recession in the drip rate. This seasonal behaviour of infiltration into the Endriagos chamber (i.e., switching between peak and base level drip rates, with periods of recession) confirms that the excess rainfall controls the seasonal variation in drip rate from year-to-year. The state of minimum recharge in the cave lasts, on average, for around 132 $( \pm 61)$ days, with a mean drip rate into the Endriagos chamber of $0.4( \pm 0.3) \mathrm{mm} / \mathrm{h}$. On the other hand, the mean duration of the maximum recharge period is approximately $93( \pm 58)$ days, with a mean drip rate into the chamber of $2.4( \pm 0.4) \mathrm{mm} / \mathrm{h}$. While the piston effect is active, evacuating the supersaturated water from the vadose zone, a number of phases can be distinguished ( and Fig. 6):

- Duration of the rainfall deficit that precedes the infiltration of the first excess rainfall $\left(t_{d}\right)$. The duration of the rainfall deficit $\left(t_{d}\right)$ gives an idea of the xericity of the summer in the vicinity of the Cueva del Agua. This period lasts, on average, for $9 \overline{0}( \pm 36)$ days, i.e., encompassing the summer months.

Filling time of the system of microfissure and pores of the vadose zone, which is a prerequisite for the piston effect to operate $\left(t_{\overline{1}}\right)$. This is the elapsed time between the onset of a period of excess rainfall and the sudden jump in drip rate and electrical conductivity of the drip water.

The filling time of the vadose zone $\left(t_{1}\right)$ that precedes the piston effect is clearly random in character: it depends on the nature of the precipitation and the mode of infiltration of the excess rainfall into the vadose zone. It might be thought that $t_{1}$ is inversely proportional to the volume of excess rainfall accumulated in the ground over the same time period. However, the relationship between these two variables does not follow a clear pattern: on occasions, the largest excess rainfall corresponds to short, intense precipitation events. These short, intense rainfalls are incorporated into the vadose zone of the karst and enter the cave by means of preferential conduits such as fractures, without dislodging the supersaturated water already accumulated in the pores and microfissures (in other words these events do not contribute to the piston effect). An example of this behaviour happened prior to the piston recharge event of March 1999 (). Previous to this piston recharge, there was a significant volume of water excess $(235 \mathrm{~mm})$, yet the value of $t_{1}$ was the highest recorded because a high proportion of water excess $(80 \%)$ fell as intense rain (more than $1.2 \mathrm{~mm} / \mathrm{h}$ and with a mean of $2.8 \mathrm{~mm} / \mathrm{h}$ ). Ignoring the previously-commented rainfall event, the average volume of excess rainfall needed to trigger the piston effect is $117( \pm 19) \mathrm{mm}$, and the average filling time $\left(t_{1}\right)$ of the vadose zone that forms the roof of the Endriagos chamber is $26( \pm 10)$ days.

- $\quad$ Evacuation time of the supersaturated water into the Endriagos chamber by dripping $\left(t_{\overline{2}}\right)$. This is indicative of the duration of the piston effect. It equates to the time between the end of the water-filled of voids in the vadose zone $\left(t_{\overline{1}}\right)$ and the start of the fall in electrical conductivity of the drip water.

The duration of the piston effect $\left(t_{2}\right)$ varies from 5 to 10 days. It represents the time needed to dislodge the supersaturated water mass held in the vadose zone. As above, one can conceive that $t_{2}$ should be inversely proportional to the excess rainfall accumulated during the filling time $\left(t_{1}\right)$, since a larger volume of accumulated water exerts a greater pressure on the supersaturated water mass. However, part of this volume of excess rainfall comes from intense rainfall events, whereby the water drains into the cave via preferential conduits and does not intervene in the piston effect. Thus, there is no clear inverse relationship between $t_{2}$ and the volume of excess rain that falls beforehand.

- Emptying time of the infiltration water $\left(t_{3}\right)$ derived from the most recent excess rainfall events. The volume of drip water dislodged into the Endriagos chamber will not correspond with the total water excess that infiltrates into the vadose zone associated with the dripping. In fact, total water excess is difficult to quantify because of the heterogeneity of the karst, which retains water in the system of microfissure and pores of the vadose zone. Graphically, $t_{3}$ will be the period over which the electrical conductivity of the drip water in the Endriagos chamber diminishes to its base level, which signals the onset of a period of water deficit and a state of minimum recharge. The value of $t_{3}$ is approximate, since it is common for there to be a series of peak excess rainfall events after the end of the piston effect.

The emptying time of the infiltration water $\left(t_{3}\right)$ is indicative of the duration of dripping into the Endriagos chamber before the minimum stable level is reached (period of deficit). The quantity of rainfall during the filling time $\left(t_{1} \cong 1\right.$ month) is essential to understanding this process, since it produces the accumulation of water 


\begin{tabular}{|c|c|c|c|c|c|}
\hline DATE & $T_{d}$ & $\mathrm{~T}_{1}$ & $\mathrm{~T}_{2}$ & $\mathrm{~T}_{3}$ & WATER EXCESS \\
\hline Sep-Oct/1997 & - & $12 \mathrm{~d} 22 \mathrm{~h}$ & $6 \mathrm{~d} 20 \mathrm{~h}$ & $177 \mathrm{~d}$ & $133 \mathrm{l} / \mathrm{m}^{2}$ \\
\hline April/1998 & $42 \mathrm{~d}$ & $16 d$ & $10 \mathrm{~d}$ & $103 d$ & $108 \mathrm{l} / \mathrm{m}^{2}$ \\
\hline March/1999 & $105 d$ & $161 \mathrm{~d}$ & $9 d$ & $94 \mathrm{~d}$ & $235 \mathrm{l} / \mathrm{m}^{2}$ \\
\hline October/1999 & $97 \mathrm{~d}$ & $31 \mathrm{~d} 12 \mathrm{~h}$ & $7 d$ & $135 d$ & $141 \mathrm{l} / \mathrm{m}^{2}$ \\
\hline April/2000 & $57 \mathrm{~d}$ & $26 \mathrm{~d} 12 \mathrm{~h}$ & $7 \mathrm{~d} 6 \mathrm{~h}$ & $105 d$ & $92 \mathrm{l} / \mathrm{m}^{2}$ \\
\hline November/2000 & $140 \mathrm{~d}$ & $39 d$ & $5 \mathrm{~d} 12 \mathrm{~h}$ & - & $123 \mathrm{l} / \mathrm{m}^{2}$ \\
\hline October/2001 & $101 d$ & $27 d$ & $9 d$ & $202 d$ & $105 \mathrm{l} / \mathrm{m}^{2}$ \\
\hline
\end{tabular}

Table 3. Duration of the different processes implicated in a rapid recharge event in the cave by means of the piston effect $\left(t_{\mathrm{d}}\right.$ : duration of the water deficit in the terrain; $\mathrm{t}_{1}$; filling time of water in the system of microfissure and pores; $\mathrm{t}_{2}$ : duration of the piston effect and $\mathrm{t}_{3}$ : "emptying" time of the vadose zone).

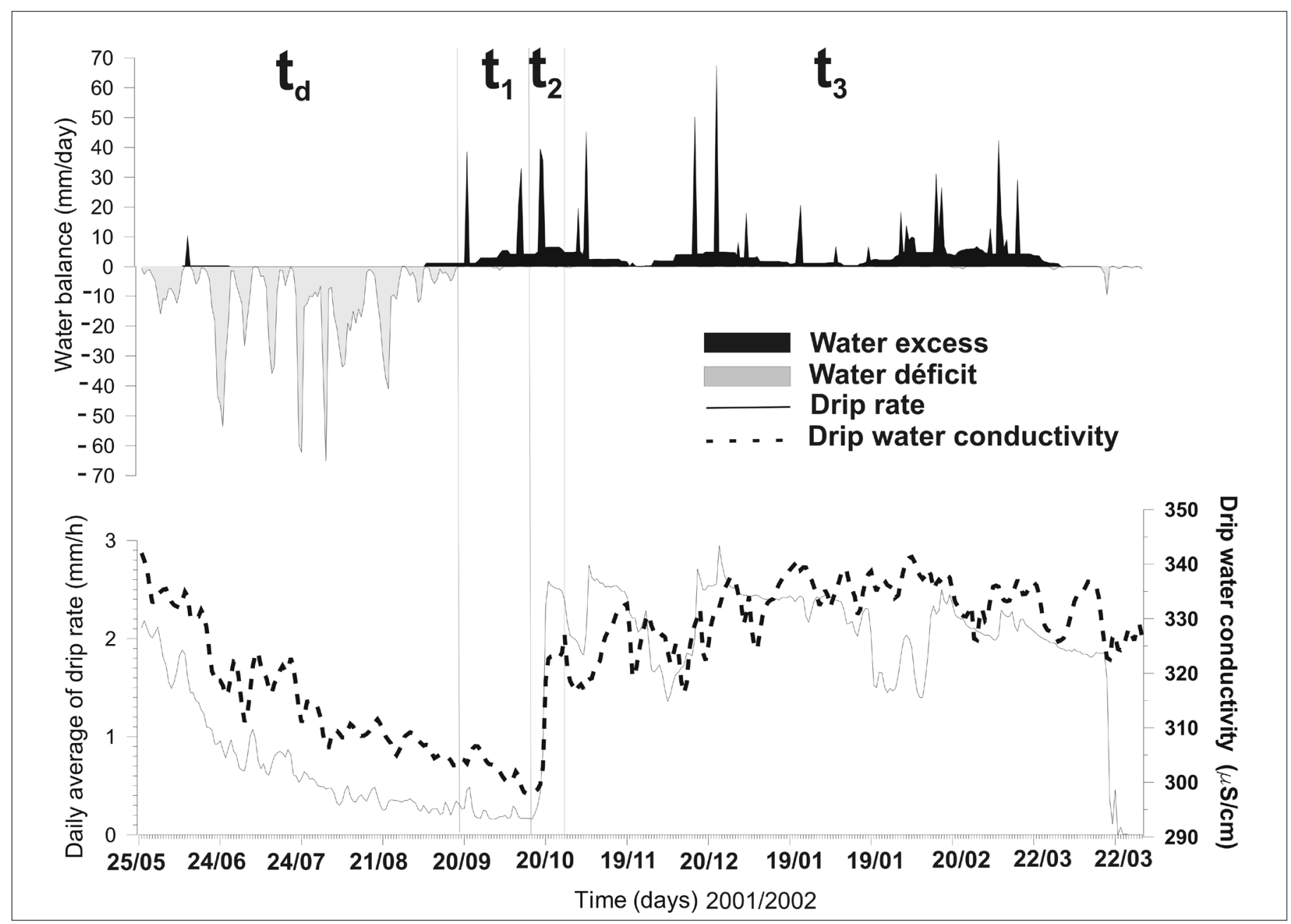

Fig. 6. Example of increase in dripping due to the piston effect in the Endriagos chamber for 2001/2002. (td: duration of the water deficit in the terrain; $\mathrm{t} 1$; filling time of water in the system of microfissure and pores; $\mathrm{t} 2$ : duration of the piston effect and t3: "emptying" time of the vadose zone).

in the vadose zone that is sufficient to cause a sudden increase in the drip rate. In other caves, $a t_{1}$ of 1-3 months is cited (Genty \& Deflandre, 1998, Père Nöel cave in Belgium). The greater the volume of water accumulated in the vadose zone during $t_{1}$, the greater the increase in the drip rate in the Endriagos chamber recorded during the rapid recharge events (Fig. 7). The biggest impact of the accumulated precipitation is detected during the infiltration of the autumn months, when the volume of precipitation that fell over the previous month is greater (between 150 and $350 \mathrm{~mm}$ ). In the Endriagos chamber, the sudden autumn increase in drip rate varies from 2.4 to 2.8 $\mathrm{mm} / \mathrm{h}$. During the spring events the accumulated rainfall from the previous month ranges from 50 to $75 \mathrm{~mm}$, and so the infiltration does not increase to the same extent (between 1.5 and $1.9 \mathrm{~mm} / \mathrm{h}$ for the Endriagos chamber). The mean monthly accumulated precipitation over the hydrological years 1997-2002 is around $75 \mathrm{~mm}$, a limit value that differentiates the rapid recharge events of rainfall into the cave occur in spring from those occurring in autumn (Fig. 7). In spring, increased infiltration into the cave mediated by the piston effect is usually favoured because of the thaw of snow that has fallen over the winter months - a common phenomenon at this altitude.

The increase in drip rate into the Endriagos chamber with respect to the volume of rainfall accumulated 
during the previous month can be fitted to a logarithmic function of the type $y=a \cdot \ln (x)+b$, where $\mathrm{x}$ is the rainfall accumulated over the previous month and $y$ is the increase in drip rate. The coefficients a and $b$ indicate how the drip rate varies as a function of rainfall accumulated during the previous month. The coefficient a is the slope, or coefficient of change, of the drip rate as a function of the accumulated precipitation. Coefficient $b$ represents the variation in drip rate during piston recharge for a unit increase in the volume of rainfall accumulated over the previous 30 days. The increase in drip rate $(\mathrm{y}$, in $\mathrm{mm} / \mathrm{h})$ in the Endriagos chamber during an increase infiltration event is correlated with the rainfall accumulated in the previous month ( $\mathrm{x}$, in $\mathrm{mm})$, according to the following function:

$\mathrm{y}(\mathrm{mm} / \mathrm{h})=0.55 \cdot \ln (\mathrm{x})(\mathrm{mm})-0.55 ; \quad\left(\mathrm{R}^{2}=0.94\right)$ The mean drip rate can be used as a reference value: over periods of maximum and minimum drip rate into the cave $(2.4 \mathrm{~mm} / \mathrm{h}$ and $\approx 0.4 \mathrm{~mm} / \mathrm{h}$, respectively), a change in the type of infiltration regime is detected in the Endriagos chamber by a mean increase in drip rate of $\pm 2 \mathrm{~mm} / \mathrm{h}$. Substituting it into the equation above shows that a change away from a state of infiltration in the cave by means of the piston effect requires 107 $\mathrm{mm}$ of rainfall over the previous month (with extreme values between 32 and $327 \mathrm{~mm} /$ month). The value of $107 \mathrm{~mm} / \mathrm{month}$ (mm/month) is not far from the mean water excess of $117( \pm 19) \mathrm{mm} / \mathrm{month}$ calculated for the seven events of increased infiltration due to the piston effect discretised above .

Another fundamental variable correlated with the sudden jump in the drip rate in the cave is the maximum mean daily rainfall prior to the start of the evacuation of the vadose zone by the piston effect (Fig. 7Fig. ). This volume of water definitively unleashes the increased discharge into the cave if the fissures and pores in the vadose zone are full. Again, the relationship between the two variables can be fitted to a logarithmic function $y=a \cdot \ln (x)+b$, where $x$ is the maximum mean daily rainfall over the month prior to the piston effect, and y is the increase in drip rate in the Endriagos chamber. Coefficient a has the same definition as before. Coefficient $b$ represents the variation in drip rate during a piston effect event for a unit increase in the maximum rainfall in $\overline{2} 4 \mathrm{~h}$, recorded in the weather station outside the cave. The increase in drip rate $(\mathrm{y}$, in $\mathrm{mm} / \mathrm{h})$ in the Endriagos chamber during one of these events of increased infiltration is correlated to the maximum mean daily rainfall $(\mathrm{x}, \mathrm{mm} / \mathrm{h})$ over the month prior to the onset of the piston effect, according to the following function:

$\mathrm{y}(\mathrm{mm} / \mathrm{h})=0.59 \cdot \ln (\mathrm{x})(\mathrm{mm} / \mathrm{h})+1.86 ; \quad\left(\mathrm{R}^{2}=0.98\right)$

Similarly, it is estimated that a rainfall maximum of 1 to $1.3 \mathrm{~mm} / \mathrm{h}$ could trigger the start of the piston effect, provided that the vadose system of microfissure

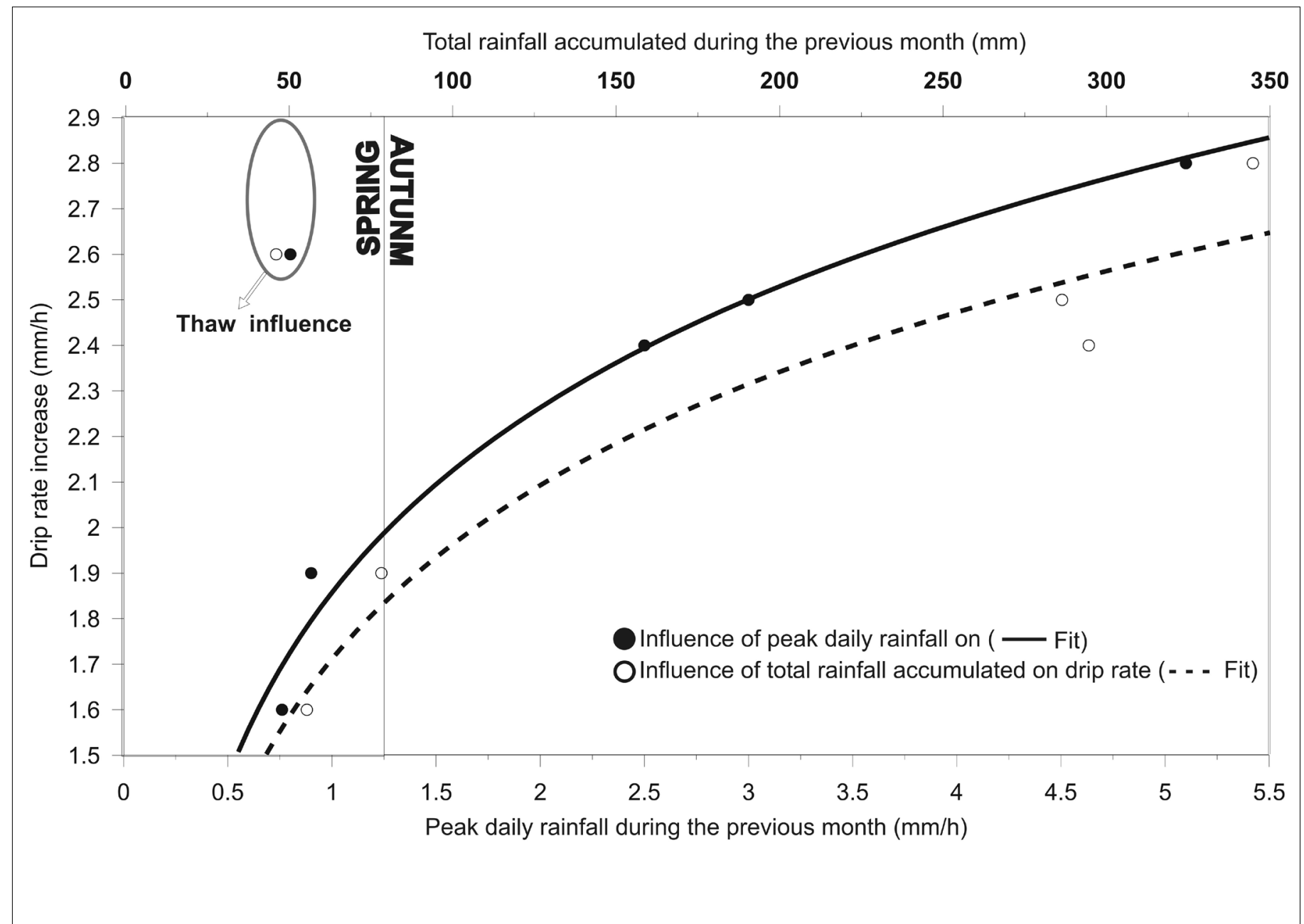

Fig. 7. Influence on drip rate into the Endriagos chamber of peak daily rainfall prior and of total rainfall accumulated during the previous month (data refer to events of rapid increase in infiltration into the cave). 
and pores is full of water.

The March 1999 change in the infiltration pattern differs significantly from the behaviour described above. It does not fit the logarithmic regression functions (Fig. 7). Prior to March 1999, the volume of excess rainfall was elevated $(235 \mathrm{~mm})$, yet $t_{1}$ was the highest recorded $(161 \mathrm{~d})$. During $t_{1}$ the proportion of water excess respect was high $(80 \%)$ as a result of a series of intense rainfall events (all exceeding $1.2 \mathrm{~mm} /$ $\mathrm{h}$ and with a mean of $2.8 \mathrm{~mm} / \mathrm{h}$ ). Most of the excess volume had to be incorporated into the ground and towards the cave along preferential flow paths, without contributing to the piston effect on the supersaturated water reserve already held in the vadose zone. The long duration of $t_{1}$ leads one to think that the change in the infiltration regime brought into play a further source of water, such as precipitation falling as snow. At this time of year, and at this altitude (the Cueva del Agua lies $1746 \mathrm{~m}$ asl.), the freezing of snow frequently occurs, especially during the early morning. This would slow down infiltration of snowmelt into the ground, so lengthening the period needed for the microfissures and pores in the vadose zone to fill up, and postponing the start of the piston effect $\left(t_{1}\right)$.

\section{Air-pressure-induced drip rate variations}

Another parameter that influences drip rate is a change in barometric air pressure inside the cave. Mean oscillation of air pressure in the cave is 10.0 $\pm 3.7 \mathrm{mbar}$, and this leads to a variation in drip intensity of $0.5 \pm 0.2 \mathrm{~mm} \cdot \mathrm{h}^{-1}$ (Fernandez-Cortes et al., 2007). An increase in air pressure within the cave causes a similar increase in pressure in the air held in the network of fissures and pores associated with the drip water. This rise in pressure is translated as an increase in the relative thickness of the gaseous phase at the cost of the aqueous one; thus the drip rate from the stalactite falls. This dynamic equilibrium of the drip water, governed by changes in pressure, disappears as the water excess peaks, or when the supersaturated water reserves of the vadose zone are mobilized. During these periods, rises in air pressure inside the cave are insufficient to reduce the thickness of the liquid phase in the conduits around the drip discharge, and so the pressure exerted by the film of infiltration water prevails over that of the gaseous phase of the drip water.

These barometric effects on drip rate last for 2-3 days and are not dependent on excess rainfall and water in the vadose zone (Fig. 8). Although this effect is more evident when rainfall excess and water infiltration in the vadose zone are lower (base flow during summer months). Thus, daily correlation can be established between variations in air pressure (external and inside cave) and drip rate during time with minimum values. Similar effects have been detected in small drip discharges from cave stalactites (Genty \& Deflandre, 1998; Baker \& Brunsdon, 2003). These cases were explained either by a 'shut-off faucet' process due to the rock-formation stress, or to a change in the proportions in a two-phase flow (air and water).

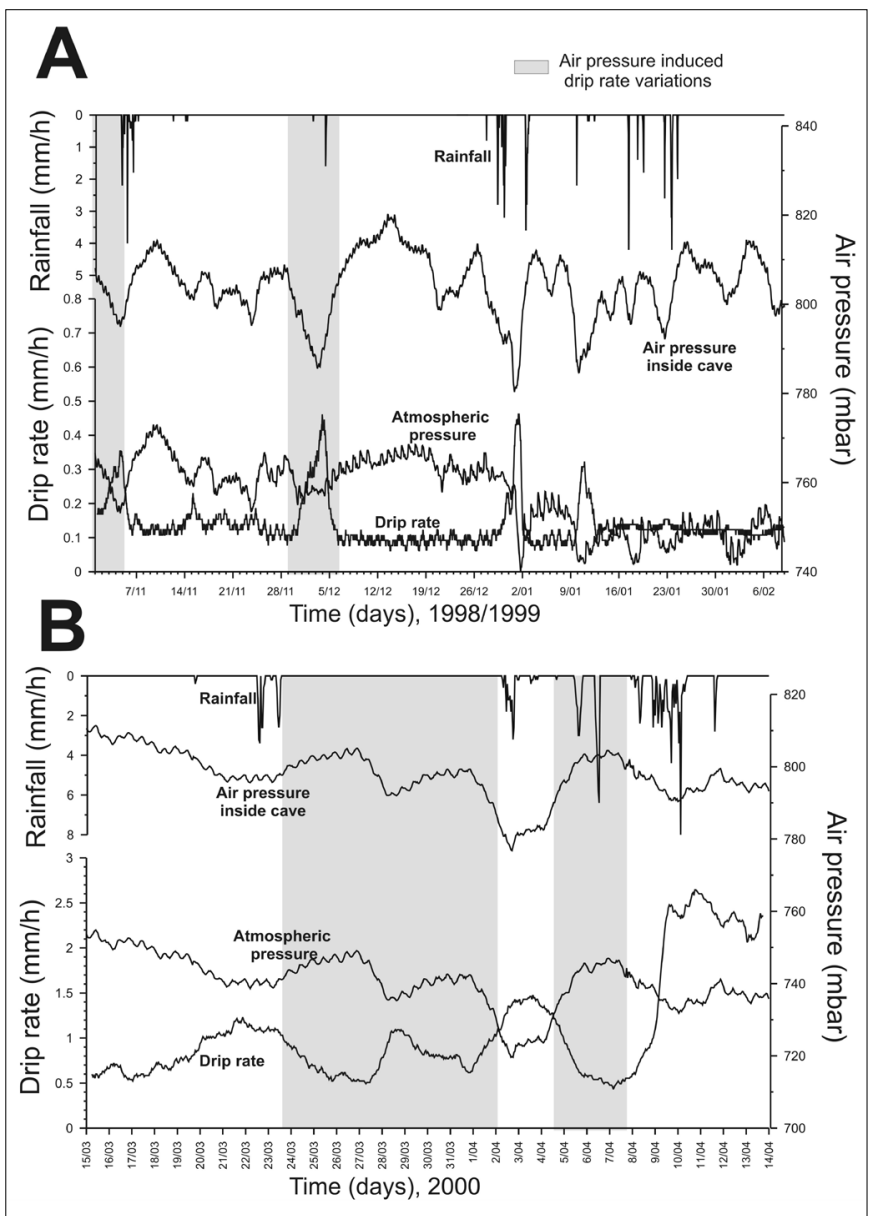

Fig. 6. Example of increase in dripping due to the piston effect in the Endriagos chamber for 2001/2002. (td: duration of the water deficit in the terrain; $\mathrm{t} 1$; filling time of water in the system of microfissure and pores; $\mathrm{t} 2$ : duration of the piston effect and $\mathrm{t} 3$ : "emptying" time of the vadose zone).

It would be highly interesting to compare the results from studies in other caves at different depths, in different geological, structural or climatic regions, in order to describe the absence of linearity of the infiltration process over time in karstic terrain, particularly that associated with caves.

\section{DISCUSSION AND CONCLUSIONS}

Ingeneral, the dripwater dischargeinto the Endriagos chamber of the Cueva del Agua is not seasonal but is linked to processes of slow infiltration. The point changes in the drip regime from non-seasonal to seasonal are related to intense precipitation events in the exterior that provoke increased variability of the drip rate. The marked falls in the drip rate in the Endriagos chamber after long periods of water deficit may even halt the dripping completely.

Variation in drip rate from the stalactite basically depends on the piston effect and on changes in air pressure in the interior of the cave. The mechanism of these two phenomena can be summarised as follows:

On a year-to-year time scale, the drip rate depends on the seasonality of rainfall. However, sudden rises in the drip rate $(>1.5 \mathrm{~mm} / \mathrm{h})$ are observed, due to the flow of infiltration water along preferential 
conduits as well as due to the evacuation of reserves of water by means of the piston mechanism. Seasonal changes in drip rate are longer and more gradual. In contrast, sudden changes in infiltration regime are observed due to the mobilization of water reserves held in the microfissures and pores. These events last between 5 and 10 days (the time taken to evacuate the supersaturated water by dripping into the Endriagos chamber). Both types of drip rate regime in the Endriagos chamber are related to excess rainfall or with the type of infiltration in the unsaturated zone.

The phase of least recharge into the Endriagos chamber lasts, on average, for 132 days $(\sigma=61 \mathrm{~d})$, with a mean drip rate of $0.4 \mathrm{~mm} / \mathrm{h}(\sigma=0.26 \mathrm{~mm} /$ h). In turn, the mean duration of peak recharge into the cave is 93 days $(\sigma=58 \mathrm{~d})$, with a mean drip rate of $2.4 \mathrm{~mm} / \mathrm{h}(\sigma=0.37 \mathrm{~mm} / \mathrm{h})$. In order for the piston effect to be triggered and so cause a change from a state of discharge, a mean accumulation of $117 \pm 18.7 \mathrm{~mm}$ of excess rainfall in the vadose zone is required. This is achieved, on average, after $25.5 \pm 9.7$ days. During the rapid recharge events that take place in the Endriagos chamber (especially during the autumn) the greater the volume of water accumulated in the vadose zone over the previous month, or the heavier the peak rainfall over the previous few days, the larger the increase recorded in the drip rate in the chamber.

The influence of air pressure changes is also detected in the drip rate in the Endriagos chamber; a mean oscillation of air pressure inside the cave of $10 \mathrm{mbar}$ ( $\sigma=3.7 \mathrm{mbar}$ ) is translated into a mean variation in drip rate in the Endriagos chamber of $0.5 \mathrm{~mm} / \mathrm{h}$ $(\sigma=0.2 \mathrm{~mm} / \mathrm{h})$. An increase in air pressure inside the cave provokes a similar increase in the gaseous phase in the fissure and pore network associated with the dripping. This increase of air pressure causes an increase in the relative thickness of the gaseous phase of the drip water, to the detriment of the liquid phase. Thus, the drip rate from the stalactite is reduced. This relative equilibrium of the drip water, determined by changes of pressure, is overruled when the piston effect operates. During piston recharge, the increases in interior air pressure are insufficient to reduce the thickness of the liquid phase in the conduits close to the stalactite, and the pressure exerted by the lamina of infiltration water on the gaseous phase of the drip water prevails.

The results confirm several previous features observed by Genty \& Deflandre (1998) and Baker \& Brunsdon (2003), as well as reinforce the knowledge about the water infiltration, storage and percolation in the vadose zone of karst: (1) increased discharge is accompanied by an increase in conductivity, which suggests that the flushed water is more mineralized and was stored in the karst aquifer for several months; (2) the drip regime of the stalactite is driven by the atmospheric pressure changes, which is explained by either a 'shut-off faucet' process due to the rockformation stress, or to a change in the two-phase flow component proportions (air and water).

\section{ACKNOWLEDGEMENTS}

We are sincerely grateful for all the help given by the "Diputación Provincial of Granada" and especially to Manuel González Ríos, who is responsible for management of the Cueva del Agua. A. FernandezCortes benefits from a postdoctoral grant supported by the Spanish Ministry of Education and Science through the Research Programme "Juan de la Cierva". This study has been undertaken within the framework of the research projects: CGL2006-01707/BTE, supported by the Spanish Ministry of Education and Science, and IGCP-513 project financed by UNESCO. We sincerely thank to the journal reviewers for their valuable comments and suggestions for improving the manuscript.

\section{REFERENCES}

Baker A., Barnes W.L. \& Smart P.L., 1997 - Variations in the discharge and organic matter content of stalagmite drip waters in Lower Cave, Bristol. Hydrological Processes, 11 (11): 1541-1555.

Baker A. \& Barnes W.L., 1998 - Comparison of the luminescence properties of waters depositing flowstone and stalagmites at Lower Cave, Bristol. Hydrological Processes, 12 (9): 1447-1459.

Baker A., Genty D. \& Fairchild I.J., 2000 - Hydrological characterisation of stalagmite dripwaters at Grotte de Villars, Dordogne, by the analysis of inorganic species and luminescent organic matter. Hydrology and Earth System Sciences, 4 (3): 439-449.

Baker A. \& Brunsdon, C., 2003 - Non-linearities in drip water hydrology: an example from Stump Cross Caverns, Yorkshire. Journal of Hydrology, 277 (3-4): 151-163.

BarMatthews M., Ayalon A., Matthews A., Sass, E. \& Halicz L., 1996 - Carbon and oxygen isotope study of the active water-carbonate system in a karstic Mediterranean cave: Implications for paleoclimate research in semiarid regions. Geochimica et Cosmochimica Acta, 60 (2): 337-347.

Calaforra J.M., Fernandez-Cortes A., Sanchez-Martos F., Gisbert J. \& Pulido-Bosch A., 2003 - Environmental control for determining human impact and permanent visitor capacity in a potential show cave before tourist use. Environmental Conservation, 30 (2): 160-167.

Cardenal J., Benavente J., Andreo B. \& Carrasco F., 1999 - Modelización hidrogeoquímica del agua de infiltración en la Cueva de Nerja (Málaga). Geogaceta, 25: 63-65.

Carrasco F., Andreo B., Benavente J. \& Vadillo I., 1995 - Chemistry of the water in the Nerja Cave System (Andalusia, Spain). Cave and Karst Science, Transactions of the British Cave Research Association, 21 (2): 27-32.

Chapman J.B., Ingraham N.L. \& Hess J.W., 1992 - Isotopic Investigation of Infiltration and Unsaturated Zone Flow Processes at Carlsbad Cavern, New-Mexico. Journal of Hydrology, 133 (3-4): 343-363.

Covelli S., Cucchi F. \& Mosca R., 1998 - Monitoring of percolation water to discriminate superficial inputs in a karst aquifer. Environmental Geology, 36 (3-4): 296-304. 
Cruz F.W., Karmann I., Magdaleno G.B., Coichev N. \& Viana O., 2005 - Influence of hydrological and climatic parameters on spatial-temporal variability of fluorescence intensity and DOC of karst percolation waters in the Santana Cave System, Southeastern Brazil. Journal of Hydrology, 302 (1-4): 1-12.

Digital Analog Systems, 1993 - Manuale d'uso del Thermos Data. Digital Analog Systems, Rome (Italy).

Fairchild I.J., Borsato A., Tooth A.F., Frisia S. \& Hawkesworth C.J., Huang Y.M., McDermott F., Spiro B., 2000-Controlson trace element (Sr-Mg) compositions of carbonate cave waters: implicationsforspeleothemclimaticrecords. ChemicalGeology, 166 (3-4): 255-269.

Fairchild I.J., Tuckwell G.W., Baker A. \& Tooth A.F., 2006 Modelling of dripwater hydrology and hydrogeochemistry in a weakly karstified aquifer (Bath, UK): Implications for climate change studies. Journal of Hydrology 321 (1-4): 213-231.

FairchildI.J., ToothA., BorsatoA. \&FrisiaS., 2007-Speleothems. In: Nash, D.J., McLaren, S.J. (Eds.), Geochemical Sediments and Landscapes. Blackwells, Oxford (7).

Fernandez-Cortes A., Calaforra J.M. \& Sanchez-Martos F., 2006 - Spatiotemporal analysis of air conditions as a tool for the environmental management of a show cave (Cueva del Agua, Spain). Atmospheric Environment, 40 (38): 7378-7394.

Fernandez-Cortes A., Calaforra J.M., Sanchez-Martos F. \& Gisbert J., 2007 - Stalactite drip rate variations controlled by air pressure changes: an example of non-linear infiltration processes in the 'Cueva del Agua' (Spain). Hydrological Processes, 21 (7): 920-930.

Fernández-Cortes A., 2005 - Caracterización microclimática de cavidades y análisis de la influencia antrópica de su uso turístico. Servicio de Publicaciones de la Universidad de Almería, Almería (Spain), 424 p.

Genty D. \& Deflandre G., 1998 - Drip flow variations under a stalactite of the Pere Noel cave (Belgium). Evidence of seasonal variations and air pressure constraints. Journal of Hydrology, 211 (1-4): 208-232.

González-Ríos M.J. \& Marín-Maldonado J.C., 1994 - La Cueva del Agua. Granada, Spain. Diputación Provincial de Granada, Granada (Spain), 100 p.

Huang H.M., Fairchild I.J., Borsato A., Frisia S., Cassidy N.J., McDermott F. \& Hawkesworth C.J., 2001 - Seasonal variations in $\mathrm{Sr}, \mathrm{Mg}$ and $\mathrm{P}$ in modern speleothems (Grotta di Ernesto, Italy). Chemical Geology, 175 (3-4): 429-448.

Huang H.M. \& Fairchild I.J., 2001- Partitioning of $\mathrm{Sr}^{2+}$ and $\mathrm{Mg}^{2+}$ into calcite in karst-analogue experimental solutions. Geochimica et Cosmochimica Acta, 65: 47-62.

Kaufman A., Bar-Matthews M., Ayalon A. \& Carmi I., 2003- The vadose flow above Soreq Cave, Israel: a tritium study of the cave waters. Journal of Hydrology, 273 (1-4), 155-163.
Li B., Yuan D.X., Qin J.M., Lin Y. \& Zhang M.L., 2000Oxygen and carbon isotopic characteristics of rainwater, drip water and present speleothems in a cave in Guilin area, and their environmental meanings. Science in China Series D-Earth Sciences, 43 (3): 277-285.

McDonald J. \& Drysdale R., 2007- Hydrology of cave drip waters at varying bedrock depths from a karst system in southeastern Australia. Hydrological Processes, 21: 1737-1748.

Musgrove M. \& Banner J.L., 2004- Controls on the spatial and temporal variability of vadose dripwater geochemistry: Edwards Aquifer, central Texas. Geochimica et Cosmochimica Acta, 68 (5): 10071020.

Pérez-López A., 1986 - Estratigrafia y estructura del sector noroccidental de la sierra Harana (Subbético interno, Cordillera Bética). Mediteranea serie de estudios geológicos, 5: 147-156.

Perrin K., Jeannin P.Y. \& Zwahlen F., 2003 - Epikarst storage in a karst aquifer: a conceptual model based on isotopic data, Milandre test site, Switzerland. Journal of Hydrology, 279 (1-4): 106-124.

Smart P.L. \& Friederich H., 1987 - Water movement and storage in the unsaturated zone of a maturely karstified aquifer, Mendip Hills, England. Conference on Environmental Problems in Karst Terrains and Their Solution. National Water Well Association, Bowling Green (Kentucky, USA) pp. 57-87.

Sondag F., van Ruymbeke M., Soubies F., Santos R., Somerhausen, A., Seidel, A. \& Boggiani, P., 2003 Monitoring present day climatic conditions in tropical caves using an Environmental Data Acquisition System (EDAS). Journal of Hydrology, 273 (1-4): 103-118.

Tatar E., Mihucz V.G., Zambo L., Gasparics T. \& Zaray G., 2004 - Seasonal changes of fulvic acid, Ca and Mg concentrations of water samples collected above and in the Beke Cave of the Aggtelek karst system (Hungary). Applied Geochemistry, 19 (11): 1727-1733.

Thornthwaite C.W., 1954 - The measurement of potential evapotranspitation. Mather Publications \& Designs, Seabrook, New Jersey, USA.

Tooth A.F. \& Fairchild I.J., 2003 - Soil and karst aquifer hydrological controls on the geochemical evolution of speleothem-forming drip waters, Crag Cave, southwest Ireland. Journal of Hydrology, 273 (1-4): 51-68.

Van Beynen P., Ford D. \& Schwarcz H., 2000 - Seasonal variability in organic substances in surface and cave watersatMarengo Cave, Indiana. HydrologicalProcesses, 14 (7): 1177-1197.

Van Beynen P.E., Schwarcz H.P., Ford D.C. \& Timmins G.T., 2002 - Organic substances in cave drip waters: studies from Marengo Cave, Indiana. CanadianJournalofEarthSciences, 39 (2), 279-284. 